\title{
Opas mainonnan maailmaan
}

NandoMalmelin (2003). Mainonnan lukutaito. Gaudeamus.

\section{Nando Malmelin raottaa ovea mainonnan maailmaan teokses-} saan Mainonnan lukutaito (2003). Kirja käsittelee niin mainonnan historiaa, tuotantoa, ilmaisukeinoja kuin vastaanottoakin ja antaa työkaluja sekä mainonnan teoreettiseen että käytännölliseen analyysiin. Kirjoittaja perustelee tutkimuksen tarpeellisuutta sillä, ettei alalla ole juurikaan aiempaa suomenkielistä kirjallisuutta. Lisäksi mainonnan lukutaito ymmärretään tutkimuskirjallisuudessa usein osanalaajempaa medialukutaidon käsitettä. Mainonnan lukutaito on joukko valmiuksia, joita tarvitsemme päivittäisen mainostulvan kohtaamiseen. Teos käsittelee mainontaa ennen kaikkea viestintäprosessina.

Mainonnasta on olemassa lukemattomia määritelmiä. Useimpiin määritelmiin liittyy kirjoittajan mukaan se ongelma, että ne rajaavat ulkopuolelle osan mainonnan ilmiöistä.

Mainonnan ilmaisukeinot ja -kanavat uudistuvat jatkuvasti. Mielikuvamainonta on yksi ajankohtaisista ilmiöistä. Tuotekeskeisen mainonnan sijaan yritykset pyrkivät luomaan brändejä. Toinen huomionarvoinen piirre on mainosten autonomia. Mainokset liittyvät yhä vähemmän itse tuotteisiin - ne ovat monitulkintaisia ja epäsuoria. Intertekstuaaliset mainokset taas lainaavat kerronnassaan tunnettuja myyttejä, hahmoja tai tarinoita niin kirjallisuudesta, elokuvista kuin ympäröivästä kulttuuristakin.

Malmelin esittää, että mainontaa voidaan muiden mediasisältöjen tapaan pitää omana genrenään. Mainokset siis noudattavat tiettyjä ilmaisutapoja eli genrekonventioita, joista ne voidaan tunnistaa juuri mainoksiksi. Kirjoittaja pohtii myös mainosten suhdetta muihin medioihin sekä niiden lajityyppeihin. Genre on ennen kaikkea viestijän ja vastaanottajan välinen sopimus, joka määrittelee myös tulkinnan lähtökohdat. Viestin tunnistaminen mainokseksi ohjaa tulkintaamme.

Mainontaan on perinteisesti suhtauduttu varauksella. Pelot ovat kohdistuneet ennen kaikkea mainonnan vaikutuksiin, vaikka niitä ei kyetäkään luotettavasti osoittamaan. Vaikutusten pelossa erityisesti lapsia on pyritty suojaamaan. Mainontaa säännelläänkin sekä laeilla että itsesääntelyn keinoin. Kriittisen suhtautumisen taustalla ovat olleet myös mainonnan kaupalliset tavoitteet. Mainontaa käytetään toisaalta myös yhteiskunnallisesti arvokkaiden asioiden edistämiseen. Mainonnan ja joukkoviestinten vuorovaikutus on ollut kiinteä mainonnan syntymästä alkaen, sillä sanomalehdet sekä kaupalliset radio- ja televisiokanavat rahoittavat toimintaansa mainostuloilla.

Mainostajat lähestyvät kuluttajia kohderyhminä, joita luokitellaan erilaisin kriteerein. Toisaalta demografiset tekijät kuten ikä tai asuinpaikka eivät selitä suoraviivaisesti yksilön kulutuskäyttäytymistä. Mainostajat joutuvatkin keksimään jat- kuvasti uusia keinoja tavoittaakseen kuluttajat näiden jakautuessa yhä pienempiin osayleisöihin kulutustottumusten ja mieltymysten mukaan.

Malmelin esittelee mainonnan analyysin tueksi useiden mediateoreetikkojen ajatuksia Roland Barthesista Stuart Halliin ja John Fiskestä Jürgen Habermassiin. Kirja tarjoaakin käytännöllisen näkökulman mediatutkimuksen klassikkoteorioihin. Esimerkkeinä kirjoittaja käyttää muun muassa Benettonin, Dieselin ja Soneran mainoskampanjoita.

Mainokset ovat mediatutkimukselle hedelmällistä aineistoa. Kirjoittaja esittää, että niitä tulisi tutkia nimenomaan mediasisältöinä sekä yhteiskunnallisina ilmiöinä. Kirjoittajan mukaan mainonnan tutkimuksessa keskeinen ongelma on ollut se, että tutkijat tutkivat mainonnan kautta pikemminkin muita kulttuurisia ilmiöitä ja mainontaa ainoastaan näiden ilmiöiden heijastumana. Kirjoittaja korostaa, ettei mainonta elä tyhjiössä vaan sen merkitykset ovat voimakkaasti yhteisöllisiä ja kulttuurisidonnaisia.

Kirja soveltuu oppikirjaksi niin viestinnän, yhteiskuntatieteiden kuin kaupallisen alankin perusopintoihin sekä kaikille mainonnan saloista kiinnostuneille. Kirjoittaja onnistuu vangitsemaan lukijan mielenkiinnon. Teos johdattaa lukijan samalla muillekin tiedon lähteille, sillä laaja kirjallisuusluettelo tarjoaa pureskeltavaa pitemmäksikin aikaa. 